\title{
INCREASING OF THE STUDY PROCESS ORGANIZATION EFFICIENCY IN MILITARIZED EDUCATIONAL INSTITUTION
}

\author{
Alens Indriksons ${ }^{1}$
}

\begin{abstract}
The correct organization of the study process serves as a basis for the development of theoretical knowledge and practical skills in students. The present paper explores the specificity of the study process organization in the militarized educational institution with hierarchy, discipline and one way communication. Therefore, the study process and pedagogical work is diverted into a second place, thereby reducing their effectiveness. The aim of the research is to perform a study of the professional training system of border guards to detect the factors that influence the training system and to determine the possibilities to improve and increase the organization and efficiency of the study process in the State Border Guard College. In order to explore the possibilities to increase the organization and efficiency of the study process, questionnaires for the teachers were created and factors that influence the professional training system of border guards were detected. The author brought forward the conclusion that increasing the organization and efficiency of the study process in militarized educational institution is not possible without correct and planned organization of the study process, giving priority to the study process, reducing the involvement of the students in internal service duties, and applying "subject-subject" communication in the implementation of professional and general education courses.
\end{abstract}

UDC Classification: 377; DOI: http://dx.doi.org/10.12955/cbup.v6.1221

Keywords: efficiency, priority, planning, communication.

\section{Introduction}

In a training process, the student is practically and theoretically prepared for work in a specific profession, obtaining a specific professional qualification (Miķelsone, 2005). A militarized educational institution, during the professional training process, must focus on the training of a state military official in service and on developing the skills required for service. Its work is determined and regulated by specific laws and regulations. Thus, in relation to the issue and the idea under study, we need to assess the particular features of a militarized educational institution, as well as the organization of the study process and the factors that affect it. The study was conducted in a militarized educational institution in Latvia - at the State Border Guard College. The specific nature of its educational process is determined by the Border Guard Law, which states that the Border Guard is armed, and the functions thereof are to ensure the inviolability of the State border and the prevention of illegal migration, and that a border guard is an official of the Ministry of the Interior, who ensures the fulfilment of the tasks of the Border Guard and to whom a special service rank is granted (The Border Guard Law, 1997). This means that the fulfilment of service duties has a central role in the work of the State Border Guard College as a militarized educational institution, diverging from the main aim of being an educational institution. The implementation of a quality study process, which in turn affects the development of the student's personality, as well as the role of the teacher in a specific environment is subordinated to the necessity and needs of service.

To fulfil the aims of the study process and improve the quality of the professional training of border guards, it is necessary to research factors that affect successful acquisition of a study program in a specific environment of a militarized educational institution. Thus, the aim of this study is to perform a study of the professional training system of border guards to detect factors that influence the system, and to determine possibilities to improve and increase the organization and efficiency of the study process in the State Border Guard College.

\section{Literature review}

Fryman (2002) believes that the key to successful work in any organization is quality. The use of knowledge in an individual's practical professional activity presupposes a set of special rules, which show how, in specific situations, by which means and for achieving specific aims, this or that knowledge can be used (Nikiforovs, 2007).

The Border Guard Law states that the Border Guard is armed, and a border guard is an official of the Ministry of the Interior, who ensures the fulfilment of the tasks of the Border Guard and to whom a special service rank is granted (The Border Guard Law,1997). Therefore teachers and students are both border guards at the State Border Guard College who must fulfil service duties in accordance with the orders and instructions of their superiors, and because of this, due to the need for the

\footnotetext{
${ }^{1}$ Rezekne Academy of Technologies, alensindriksons@inbox.lv
} 
fulfilment of service duties, pedagogical work is often moved to the background. The study process is especially noticeably affected by such service duties of students as internal assignments that the student fulfils during the study process. In a so called twenty-four hour assignment, the staff is assigned to maintain internal order in the unit (subordinate unit), guarding its armament, other equipment, premises and belongings (property), as well as to fulfil other internal service duties (Rules of Procedure for the Military Interior Service, 2012). In addition to this, for fulfilling service duties, before and after, time for rest is appointed in accordance with the requirements of the laws and regulations. Assignments and time for rest both happen at the expense of the study process because the student does not attend classes and does not acquire knowledge in accordance with the curriculum, which directly affects their knowledge and progress in the study process. However, we must take into account that following the program of the study process specifically promotes systematized acquisition of knowledge, which is why during the implementation of the process, deviation from the curriculum is impermissible, thus rendering the achievement of the aims of a particular subject impossible.

The Border Guard Law provides that border guards, during their performance of service duty, have the right to use physical force (The Border Guard Law, 1997). Requirements for the Health and Psychological Qualities of Officials with Special Service Ranks Managing the Ministry of the Interior System Institutions and Prisons and for Applicants for the Positions of the Officials and the Procedure for Testing the Health and Psychological Qualities (2006) point out the necessity for testing the physical condition of officials with special service ranks, with the testing procedure specified in the regulation "Requirements for the Physical Training of Officials with Special Service Ranks Managing the Ministry of the Interior System Institutions and Prisons" (2013). Thus during the study process at the State Border Guard College, a lot of attention is given to the improvement of physical training of the students, which is achieved through morning exercises organized in the day plan, as well as going to practical classes to the field training center on foot, hiking with obstacles and practical training in the field during which the acquired theoretical knowledge is applied in practice, resulting in the techniques of maneuvers and the activity of the border guards being improved. Above mentioned needs to be taken into account when planning the class schedule because during the study process the teacher's responsibility is to ensure that the students master the learning material and hence organizing an efficient teaching process is impossible if such factors that could affect achieving the aim of the study process are not considered. When creating the class schedule, we must remember that every person's activity is based on their needs and interests. The needs of the person are the main driver of their activity and action. A person's activity depends on the needs required for achieving results. Kohl and Cook (2013) defines that a person's needs are the main driver of their activity and action, and a person's activity depends on the needs necessary for achieving results-the need for self-preservation is primary, whereas the need for knowledge is only fifth in the order of priority. Berliner and Gage (1999) also point out that we cannot hope to satisfy the intellectual needs of students or cultivate their aesthetic needs while their physical and social needs are not met.

The specific nature of the study process in a militarized educational institution is mainly related to the teachers and students being in a service relationship, and in the pedagogical process the students have to acquire knowledge and practical skills in an environment where they need to balance the study process with practical service. At the State Border Guard College as one of the militarized educational institutions, the traditional educational approach dominates where the main focus is on quantitative acquisition of new knowledge, constant necessity to expand existing knowledge, raise qualifications, and the process is based on authoritarianism. The term "service" implies a relationship regulated by special rules and regulations, thus the dominant type of communication and relationship in such educational institutions is "subject- object". However, Cornelius and Faire (1992) point out that orders are believed to be one of the main causes of conflict in the communication process because each person wants to feel important and does not want to be humiliated or insulted, which stresses the dependence of partners on the speaker. Communication is a complex process characterized by a successful synthesis of information, cooperation opportunities and communication skills and affected by the needs of communication partners (the teachers and the student's) and the ability to assess the situation and choose a strategy (Lintz, 2008). Renge (2002) defines three directions of information flow descending (subject- object), ascending (object- subject) and horizontal (subject- subject). Communication is also defined as the transfer and understanding of information using shared symbols 
(Ivancevich \& Konopaske, 2011). For successful communication, mutual understanding is necessary between the sender and the receiver (Principles of Effective Business Communication, 2012).

\section{Data and methodology}

To determine the factors that affect the study process of the professional training of border guards and find a possibility to improve and raise the efficiency of achieving the aims of the study process, scientific, pedagogical and psychological literature was analyzed and evaluated, a survey of students was conducted, the data obtained was processed and analyzed, a survey of teachers was conducted too and an interpretation and content analysis of the results obtained were performed.

To explore the existing situation in the field of the organization of the study process in a militarized educational institution, a study was conducted where the opinion of the teachers and students at the State Border Guard College was determined. Based on the findings, opportunities for raising and improving the efficiency of the organization of the study process were explored. The research methods included setting research objectives, the selection of methods for data gathering, processing, analysis of the data and interpretation of the data. The following research objectives were put forward:

- Conduct a study to learn about the existing situation in the organization of the study process, which involves a survey of teachers and students;

- Process and analyze the data obtained for raising and improving the efficiency and organization of the study process for the professional training of border guards.

To ensure the validity of the data, teachers from all units involved in the fulfilment of the study process at the State Border Guard College were included in the study. The participants of the survey were State Border Guard College teachers whose length of service in the position was from 5 to 20 years.

A mixed methods approach was used in data processing and analysis, which combines or joins together quantitative and qualitative research strategies. To increase the reliability of the research results, data triangulation was used, obtaining and processing quantitative and qualitative data. Kendall's tau-b correlation analysis was performed to determine correlations for processing the quantitative data in a SPSS software environment.

\section{Results and Discussion}

To explore the existing situation and the needs of the students in the field of the organization of the study process in a militarized educational institution, a survey of the students was conducted. While surveying the students, the students' opinions on the factors affecting the organization of the study process were determined. This resulted in the conclusion that the students indicate that the main factors are scheduling the classes after lunch and after physical training, involvement in internal service assignments, the attitudes of teachers to students as subordinates, and the day plan of the militarized educational institution which determines its specific environment. A large number of respondents believe that in the fulfilment of the aims of their study process, the uppermost type of communication between a teachers and a student should be "subject - subject" communication in the hierarchical system of the State Border Guard College (see Figure 1).

The study was conducted on the existing environment in the field of organization of the study process at the State Border Guard College and creates the necessity to conduct further studies on the opportunities for raising the efficiency of the study process, as well as for increasing the communication between teachers and students in the hierarchical system of a militarized educational institution.

During the teacher's survey, the opinions of the State Border Guard College teachers on the organization of the study process were explored and found out. When responding to the open questions of the survey, the respondents were given an opportunity to describe the organization of the study process at the State Border Guard College as a militarized educational institution to determine how the factors, peculiarities and the specificity that affects the organization of the study process are described by the teachers. A content analysis of the responses was performed with the aim to make conclusions and confirm the research results obtained theoretically and through the student survey about the existing situation and the specific nature of the organization of the study process in the professional training of border guards. A content analysis of the responses resulted in the identification of factors such as the involvement of students in service organization activities (internal service 
assignments) during their studies, the strictness and certainty in the classroom during the education process, a lack of long-term planning of the study process, the use of the "subject-object" type of communication in the classroom and communication in a subordinate order. These unites signify the specificity and problems in the planning, organization and implementation of the study (teaching) process, which hinder achieving the aims defined in the study programs. The content units, categories and notions describing the factors that affect the organization of the study process identified in the survey are summarized in the Table 1.

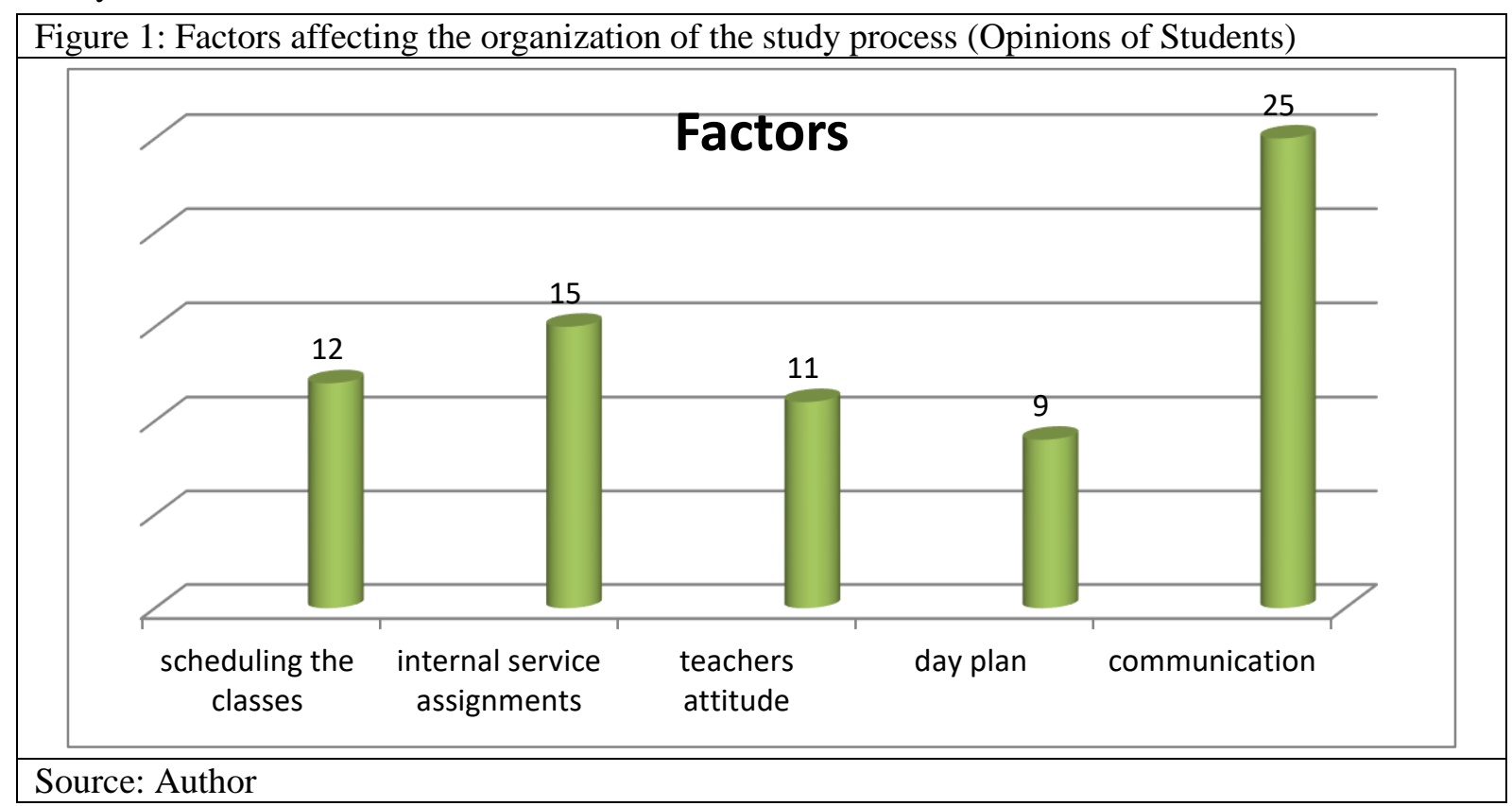

When analyzing identified notions such as "service", "discipline" and "subordination", we need to consider that for achieving the aims of the study process, it is necessary and possible to decrease or completely eliminate the involvement of students in assignments during the implementation of the study process. However, we must remember that the organization of service is the basis for successful functioning and operation of a militarized unit, whereas the study process ensures successful development of the students' skills, knowledge and abilities necessary for their professional activity. Therefore, in future discussions and studies we need to find a balance between the organization of service and the study process. A possible solution could be to delegate the guarding functions of the State Border Guard College and its units to private security units.

Table 1: The content units, categories and notions describing the factors that affect the organization of the study process

\begin{tabular}{|l|l|l|}
\hline Notion & Category & Content units \\
\hline Service & $\begin{array}{l}\text { Organization of service in an } \\
\text { educational institution }\end{array}$ & $\begin{array}{l}\text { Students during the study process are involved in } \\
\text { service organization activities (assignments) }\end{array}$ \\
\hline Discipline & $\begin{array}{l}\text { The specific environment of a } \\
\text { militarized educational } \\
\text { institution }\end{array}$ & $\begin{array}{l}\text { Strictness and certainty dominate in the institution } \\
\text { and in the classroom, which are not directed at } \\
\text { cooperation }\end{array}$ \\
\hline Subordination & Service relationship & $\begin{array}{l}\text { Students are subordinate to teachers who have the } \\
\text { right to give orders and instructions }\end{array}$ \\
\hline Programme & $\begin{array}{l}\text { Systematized acquisition of } \\
\text { knowledge }\end{array}$ & $\begin{array}{l}\text { Planning of the study process and class schedule is } \\
\text { not long-term and is constantly changing }\end{array}$ \\
\hline Planning & $\begin{array}{l}\text { Measures for planning the study } \\
\text { process }\end{array}$ & $\begin{array}{l}\text { The needs and basic requirements of students for } \\
\text { the successful acquisition of the programs are not } \\
\text { taken into account }\end{array}$ \\
\hline Communication & Direction of communication & $\begin{array}{l}\text { One-way "subject-object" communication between } \\
\text { the teacher and the student without feedback }\end{array}$ \\
\hline Orders & Form of communication & $\begin{array}{l}\text { Communication between the teacher and the student } \\
\text { takes place according to a regulated procedure }\end{array}$ \\
\hline Source: Author & \multicolumn{2}{|l}{} \\
\hline
\end{tabular}


Concerning discipline and subordination in a militarized educational institution, the author has conducted detailed research, which resulted in the conclusion that subordination, "subject- object" communication and hierarchical relationships in a militarized educational institution are the basis for the operation of the institution. The study process in a militarized educational institution needs to be created on the basis of the "subject- subject" communication type and relationship, while acquiring the understanding of accepting the hierarchical environment of a militarized educational institution as a requirement for the professional activity and effective performance of professional functions while preserving humane relationships; thus subordination will dominate in practice, however humane relationships will also be present (Indriksons, 2017). In this study the author also points out that a teacher can promote the formation of a positive attitude towards the chosen profession (Border Guard), the acceptance of the hierarchical "subject - object" communication type and relationships as a requirement for professional activity, complete understanding of what being an official is as a social role and the development of the necessary qualities of being an official (relating to an authority) by introducing subject of the Statehood (patriotic) Education and by creating an environment that promotes discipline (Indriksons, 2017). However, in further discussions we need to explore the opportunities for promoting the formation of positive attitudes towards being a border guard and accepting hierarchical relationships outside the study process in addition to involving commanders and instructors in the process during service.

When analyzing notions identified as a result of the content analysis such as "program" and "planning", we must be aware that following the program of the teaching process precisely promotes systematized acquisition of knowledge. Successful progress and organization of the study process is impossible without creating a quality class schedule, and it is one of the most important tools for organizing the study process. Considering the aforementioned, the situation where in the class schedule theoretical classes are planned after physical or practical training is impermissible because in this situation it will be virtually impossible for the pedagogues to create in the students the need for interaction, activity, constancy, knowledge, positivity in their attitude and interest towards learning, which is necessary for achieving the aims of the study process.

In the theoretical part of the research it was mentioned that at the State Border Guard College during the study process a lot of attention is given to improving the physical training of the students, which is achieved through different activities and approaches during the implementation of the study process and different educational programs. When organizing the study process and planning classes, we must take the aforementioned into account - that at the core of any person's activity, their needs and interests are primary and that after activities directed at improving physical training, the students are not immediately physically and psychologically ready for acquiring theoretical knowledge in class. This, according to the respondents, is a significant factor affecting the study process, and it needs to be considered when creating the class schedule. In future discussions we need to explore the opportunities for scheduling theoretical classes in the day plan before activities for improving physical training within the load schedule and study (academic) year plan of the State Border Guard College, as well as to explore topics in the classes and service organization activities that may hinder successful acquisition of the study process.

The notions "communication" and "orders" identified as a result of the content analysis characterize the specific nature of the operation of a militarized educational institution and its specific study process environment where fulfilment of service duties has a central role relative to the study process. Because the study process in a militarized educational institution is being fulfilled in the circumstances of a specific hierarchy and authoritarian leadership style, components such as service organization of orders, reglament and discipline create communication barriers in the study process, which significantly hinders successful achieving of the aims of the study process. The authoritarian leadership style and "subject - object" communication type in a militarized educational institution are at the basis of a service relationship and are used in its management and the study process. Therefore, we have to conclude that integration of the "subject - subject" communication type in the environment of the hierarchical system of a militarized educational institution is impossible if it is not acquired and allowed by teachers, and it is affected by limited feedback, however the teachers freedom of action is limited by the rules and regulations that regulate the military service and one way ("subject - object") communication. Thus the question for discussion is the possibility to integrate the 
"subject - subject" communication and relationship type in the specific environment of a militarized educational institution, considering that the possibility is made real by the subjects of the pedagogical process, each in their own specific activity, by expressing their attitude in interpersonal communication.

\section{Conclusion}

In accordance with the research aim to perform a study of the professional training system of border guards to detect factors that influence training system and determining the possibilities to improve the study process organization efficiency in the State Border Guard College, the conclusions were summarized as a result of a theory analysis, interpretation of the data obtained from student surveys and content analysis of teachers surveys.

Due to the hierarchy and the authoritarian leadership style that exists in a militarized educational institution, factors affecting the organziation of the study process such as the organization of the priority of service relative to the study process, an authoritarian leadership style in the classroom during the education process, inefficiency in the planning of the study process and the class schedule, the use of "subject-object" communication type in the classroom, and communication in the order of subordination were explored.

With the aim to improve the efficiency of the organization of the study process, the "subject- subject" communication and relationship type need to become the basis of communication during the study process. This will result in the students acquiring the understanding and the acceptance of the hierarchical environment of a militarized educational institution as a requirement for their professional activity in the effective fulfilment of professional functions, but at the same time preserve humane relationships. Therefore, subordination and hierarchy will dominate in service organizations, but humane relationships will be present.

Because the involvement of students in service organization activities hinders the achievement of the aims defined in the study programs, to improve the efficiency of the organization of the study process, it is necessary to decrease or completely eliminate the involvement of students in service assignments, delegating a part of the guarding functions to private units.

To protect the efficiency of the organization of the study process, it is necessary to explore the opportunities for promoting the formation of positive attitudes to the chosen profession during the implementation of the study process and outside of it, involving company commanders and instructors in the process, with the aim to help adapt more successfully to the specific environment of a militarized educational institution, thus promoting successful acquisition of the study subjects.

Considering that successful progress of the study process is impossible without creating a quality class schedule, which is one of the most important study process organization tools, when creating the class schedule, we must take into account the needs of the students, planning theoretical classes before physical or practical training, thus improving the efficiency of the organization of the study process.

\section{References}

Berliners D.C., \& Geidžs N.L. (1999). Pedagogiskā psihologija [Pedagogical Psychology]. Riga: Zvaigzne ABC. Cornelius, H., \& Faire, S. (1992). Everyone Can Win: How to Resolve Conflict. East Roseville. NSW: Simon \&Schuster.

Fiziskās sagatavotības prasības Iekšlietu ministrijas sistēmas iestā̌žu un Ieslodzījuma vietu pārvaldes amatpersonām ar speciālajām dienesta pakāpēm, (2013) [Requirements for the Physical Training of Officials with Special Service Ranks Managing the Ministry of the Interior System Institutions and Prisons]. Retrieved January 6, 2018, from https://likumi.lv/doc.php?id=257102

Fryman, M. (2002). Quality and Process Improvement. Delmar: Thomson Learning.

Indriksons, A. (2017). Komunikācijas prasmes veidošanās robežsargu profesionālajā sagatavošanā [Formation of Communication Skills in Professional Training of Border Guards]. Rezekne: Rezekne Academy of Technologies.

Ivancevich, J., \& Konopaske, R. (2011). Organizational Behavior and Management. NewYork: McGraw-Hill Irwin.

Kohl ,H. W., \& Cook,H.D. (2013). Educating the Student Body: Taking Physical Activity and Physical Education to School. Retrieved January 6, 2018, from https://www.ncbi.nlm.nih.gov/books/NBK201500/pdf/Bookshelf_NBK201500.pdf

Lintz, E. M. (2008). Conceptual Framework for the Future of Successful Research Administration. Retrieved January 6, 2018, from https://files.eric.ed.gov/fulltext/EJ888527.pdf

Miḳelsone, B. (2005). Izglītība pēc 12.klases [Education after class 12]. Riga: Profesionālās izglītības attīstības aǵentūra.

Militārā dienesta iekārtas reglaments, (2012) [Rules of Procedure for the Military Interior Service]. Retrieved January 6 , 2018, from http://www.mrcc.lv/ /media/ZS/2015/dokumenti/iekartasreglaments.ashx 
N̦ikiforovs, O. (2007). Psihologija pedagogam [Psychology for Teacher]. Riga: SIA Izglītības soḷi.

Noteikumi par Iekšlietu ministrijas sistēmas iestāžu un Ieslodzījuma vietu pārvaldes amatpersonām ar speciālajām dienesta pakāpēm un amatpersonu amata kandidātiem nepieciešamo veselības stāvokli un psihologisiskajām īpašībām un veselības stāvokḷ un psihologisko īpašību pārbaudes kārtību, (2006) [Requirements for the Health and Psychological Qualities of Officials with Special Service Ranks Managing the Ministry of the Interior System Institutions and Prisons and for Applicants for the Positions of the Officials and the Procedure for Testing the Health and Psychological Qualities]. Retrieved January 6, 2018, from https://likumi.lv/doc.php?id=149897

Principles of Effective Business Communication, (2012). Retrieved January 6, 2018, from

http://bconsi.blogspot.com/2012/12/principles-of-effective-communication-in-business.html

Reņge, V. (2002). Organizāciju psihologija [Psychology of Organization]. Riga: Kamene.

Robežsardzes likums, (1997) [The Border Guard Law]. Retrieved January 6, 2018, from https://likumi.lv/doc.php?id=46228 